\title{
PENGARUH KUALITAS PELAYANAN TERHADAP KEPUASAN KONSUMEN TOKO BANGUNAN DI SANGATTA-KUTAI TIMUR
}

\author{
Meita Sondang Rizki,SE,MM \\ Sekolah Tinggi Ilmu Ekonomi Nusantara Kutai Timur, Kaltim, Indonesia \\ Email : meitasondang@yahoo.com
}

\begin{abstract}
The study tries to identify to what extent service quality for satisfaction of consumen store building in Sangatta. Analysis model used to prove hypothesis is model analysis multiple linier regression that be analysed with using statistics computer program package, that is SPSS v. 20.0 for Windows. Furthermore it was conducted examination for validity of data by multikolinieritas test, heteroskedastisitas test and autocorrelation test. Result of statistics analysis show that coefficient of the free variables regression, that is involvement factor in tangibles $(\mathrm{X} 1)=0,161$, reliability $(\mathrm{X} 2)=0,088$, responsiveness $(\mathrm{X} 3)=0,168$, assurance $(X 4)=0,194$, emphaty $(X 5)=0,122$ and constanta equal to 0,541 . Equation of multiple linier regression is: $\mathrm{Y}=0,541+0,161 \mathrm{X} 1+0,088 \mathrm{X} 2+0,168 \mathrm{X} 3+0,194 \mathrm{X} 4+0,122 \mathrm{X} 5+\mathrm{e}$

Conclusion that receive that level of influence explained by tangibles, reliability, responsiveness, assurance, emphaty are as independent variable impact toward satisfaction of consumen store building equal to correlation coefficient (R), that is 0,860 and level of depended performance to second of free variables above is equal to determination coefficient value $\left(\mathrm{R}^{2}\right)$ that is 0,740 or $74,0 \%$. Result of analysis $\mathrm{F}$ - test indicate that all free variables by together have significant influence toward satisfaction of consumen store building in Sangatta. By partial, variable tangibles, responsiveness, assurance, emphaty have significant influence to satisfaction of consumen store building in Sangatta. Variabel independent has dominant influence to satisfaction of consumen store is tangibles.
\end{abstract}

\section{Pendahuluan}

Perdagangan retail di kabupaten Kutai Timur sepuluh terakhir berkembang pesat, khususnya di Sangatta. Hal ini ditandai dengan banyaknya pembangunan seperti gedung perkantoran, sekolah, ruko, rumah makan, pasar, rumah ibadah, jalan raya, dll. Pembangunan yang pesat berdampak positif terhadap munculnya sentra perdagangan. Toko-toko penjualan sembako, pakaian, bahan bangunan, keperluan sekolah saat ini mudah didapat. Bahkan lima tahun belakangan, di Sangatta sudah ada minimarket seperti Indomaret, Alfamart, Eramart. Seperti yang kita ketahui, perdagangan retail ini sangat berpengaruh terhadap perkembangan perekonomian di Sangatta. Perekonomian meningkat mengakibatkan jumlah penduduk ikut bertambah. Sangatta semakin ramai. Apalagi ditambah dengan adanya perusahaanperusahaan seperti KPC dan kontraktornya. Besarnya jumlah karyawan mempengaruhi peningkatan perekonomian di Sangatta. Dalam jangka waktu yang singkat, Sangatta "DISULAP" menjadi daerah yang maju dengan banyaknya bermunculan sentra perdagangan. Keramaian yang terjadi di Sangatta juga disebabkan dari banyaknya para perantau yang ikut bersaing dalam perdagangan retail. Para perantau tak ragu untuk datang dan memasuki dunia perdagangan retail ini. Perdagangan retail ini bisa menjadi alternatif yang sangat menjanjikan juga bagi karyawan yang ingin berbisinis. Itulah mengapa saat ini sangat banyak kita jumpai sentra perdagangan di Sangatta.

Kemajuan perdagangan retail yang sangat pesat ini juga ditunjang dengan tumbuhnya kesadaran masyarakat untuk membeli produk-produk retail di Sangatta meskipun harga barang bersaing dibandingkan harus membeli di kota-kota besar seperti Bontang, Samarinda, atau Balikpapan. Pertimbangan konsumen walaupun harga di kota-kota besar lebih murah, faktor jarak tempuh yang jauh dan kondisi jalan menjadi kendala. Masyarakat mau tidak mau akhirnya membeli kebutuhannya di Sangatta, kecuali bagi mereka yang rela mengeluarkan tenaga, waktu berangkat jauh ke kota besar untuk memenuhi kebutuhan mereka. Majunya perdagangan retail ini, mendorong salah satu faktor munculnya pembangunan. Pembangunan gedung pemerintahan, ruko, sekolah, tempat tinggal bagi masyarakat di 
Sangatta, termasuk yang ingin merenovasi tempat tinggalnya. Salah satu perdagangan retail yang sangat diuntungkan dengan banyaknya pembangunan-pembangunan di Sangatta ini adalah toko bahan bangunan. Toko bahan bangunan yang ada di Sangatta sekitar 25 toko. Banyaknya toko ini membuat persaingan di Sangatta sangat ketat. Persaingan yang sangat ketat tersebut memaksa pemilik toko meningkatkan kualitas pelayanan. Setiap toko berusaha memberikan segala kualitas pelayanan yang terbaik. Lupiyoadi (2001:147) mengatakan bahwa salah satu faktor yang menentukan tingkat keberhasilan dan kualitas perusahaan adalah kemampuan perusahaan dalam memberikan pelayanan kepada pelanggan. Kualitas pelayanan (servqual) merupakan the different between customer perception and expectation of service (Nitecki at al, 2000). Sedangkan Parasuraman, 1988 mendefinisikan service quality sebagai the global evaluation or attitude of overall excellent of service. Ketika konsumen melakukan konsumsi, mereka akan mengevaluasi produk atau jasa yang dikonsumsi apakah sesuai dengan yang mereka harapkan atau tidak. Kualitas pelayanan yang baik akan membuat konsumen merasa senang karena dilayani dengan baik dan dapat membuat mereka merasa puas.

Namun kepuasan nasabah tidak selalu sama, hal ini di tandai dengan pernyataan Kotler (2000) yang mengatakan bahwa kepuasan merupakan perasaan senang atau kecewa seseorang yang berasal dari perbandingan kesannya terhadap kinerja atau hasil suatu produk dan harapan - harapannya. Jika kinerja berada dibawah harapan, mengakibatkan konsumen tidak puas. Hal ini dapat membawa dampak negatif bagi perusahaan atau instansi pemerintah sehingga dapat menurunkan jumlah pelanggan atau konsumen dan menyebabkan konsumen tidak tertarik lagi menggunakan jasa instansi tersebut. Sejalan dengan pernyataan Kotler, Berry et al (1988) defined service quality is the gap between what the customers want and what they actually get or perceive they are getting. Kualitas pelayanan menjadi bermasalah apabila terdapat perbedaan antara persepsi dari keinginan konsumen dengan kenyataan yang dihadapi. Jika kenyataannya dibawah dari persepsi keinginan konsumen, maka konsumen akan menjadi kecewa, sebaliknya jika kenyataannya lebih bagus dari persepsi keinginan konsumen, maka konsumen akan merasa puas. Kotler dan Keller, 2009 mengatakan bahwa pengaruh kualitas pelayanan dan kepuasan pelanggan menjadi positif dan substansial ketika konsumen merasakan kualitas pelayanan yang tinggi, penyampaian pelayanan yang dirasakan sama atau lebih baik dari yang diharapkan oleh konsumen. Schanaar (1991) menjelaskan, pada dasarnya tujuan dari suatu bisnis/perdagangan adalah untuk menciptakan pelanggan yang merasa puas. Objek penelitian yang dilakukan penulis adalah toko bahan bangunan yang merupakan bisnis retail yang mulai berkembang. Dalam kurun waktu sepuluh tahun bisnis ini dapat membuktikan kejayaannya, namun tahun 2015 realita yang ada sebaliknya. Hal ini dapat dibuktikan dengan terjadinya penurunan omset pada beberapa toko bangunan yang ada di Sangatta. Fenomena yang jelas terlihat adalah banyaknya konsumen yang membeli bahan bangunan langsung dari Samarinda atau Surabaya.

2. Kajian Literatur

2.1. Kualitas Pelayanan

Kualitas pelayanan (servqual) merupakan the different between customer perception and expectation of service (Nitecki at al, 2000). Sedangkan Parasuraman, 1988 mendefinisikan service quality sebagai the global evaluation or attitude of overall excellent of service. Ketika konsumen melakukan konsumsi, mereka akan mengevaluasi produk atau jasa yang dikonsumsi apakah sesuai dengan yang mereka harapkan atau tidak. Kualitas pelayanan yang baik akan membuat konsumen merasa senang karena dilayani dengan baik dan dapat membuat mereka merasa puas. Kotler dan Keller, 2009 mengatakan bahwa pengaruh kualitas pelayanan dan kepuasan pelanggan menjadi positif dan substansial ketika konsumen merasakan kualitas pelayanan yang tinggi, penyampaian pelayanan yang dirasakan sama atau lebih baik dari yang diharapkan oleh konsumen. Parasuraman et. al, 1988 mengidentifikasi lima dimensi dari service quality yang menghubungkan karakteristik pelayanan yang spesifik terhadap ekspektasi konsumen, yaitu reliability, responsiveness, assurance, emphaty, tangibles. Kelima dimensi tersebut merupakan alat dasar dalam pengujian kualitas pelayanan (service quality) yang disebut SERVQUAL.

\subsubsection{Tangibles}

Merupakan appearance of physichal facility, acquipment, personal and writen materials (Alamgir dan Shamsuddoha, 2004). Menurut Zena dan Hadisumarto, 2012 tangibles merupakan the appearance of 
physical facilitise, acquipment, employees and comunication material. Dimensi ini meliputi fasilitas fisik, perlengkapan, karyawan dan sarana komunikasi. Tangibles ini merupakan bukti nyata dari kepedulian dan perhatian yang diberikan oleh para penyedia jasa untuk konsumennya. Jika perusahaan tidak memperhatikan dimensi ini, maka dapat merusak image perusahaan.

\subsubsection{Reliability}

Reliability merupakan ability to perform the promise service dependably and acurately (Alamgir dan Shamsuddoha, 2004). Dimensi reliability meliputi dua aspek utama yaitu konsistensi, kinerja dan kemampuan untuk dipercaya. Reliability bergantung pada penanganan masalah pelayanan yang dialami oleh konsuimen, memberikan pelayanan secara tepat dan sesuai waktu yang dijanjikan dan selalu menjaga error free record (Parasuraman et. al, 1988)

\subsubsection{Responsiveness}

Memiliki arti willingness to help customer and provider from service (Alamgir dan Shamsuddoha, 2004). Dimensi ini menjelaskan keinginan dan kesiapan para karyawan untuk dapat membantu konsumen dalam memberikan pelayanan dengan cepat yang dibutuhkan oleh konsumen. Dimensi ini melibatkan ketepatan waktu, pelayanan dan pemahaman pelayanan sesuai keinginan konsumen, jam operasional, perhatian individu yang diberikan oleh karyawan, perhatian terhadap masalah yang dihadapi konsumen serta keamanan dalam transaksi (Parasuraman et.al, 1985).

\subsubsection{Assurance}

Dimensi ini meliputi pengetahuan, kemampuan dan sikap rasa hormat dari masing-masing karyawan serta sikap dapat dipercaya yang dimiliki, bebas dari keragu-raguan tentang kepastian pelayanan yang diberikan agar dapat menimbulkan kepercayaan dari konsumen. Assurance merupakan employee knowledge and courtasy and their ability to inspire trust and confidence (Alamgir dan Shamsuddoha, 2004). Parasuraman et.al, 1985 memberikan pengertian assurance sebagai jaminan pengetahuan dan kesopanan karyawan dan kemampuan mereka untuk menginspirasi kepercayaan dan keyakinan.

\subsubsection{Emphaty}

Zena dan Hadisumarto (2012) menjelaskan bahwa emphaty merupakan care and provide individualisme attention to customer. Menurut Alamgir dan Shamsuddoha, 2004, emphaty merupakan caring easy acess good comunication, customer understanding and individualisme atention giceen to customer. Dimensi ini meliputi kemampuan perusahaan yang dilakukan oleh karyawan dalam memberikan perhatian kepada konsumen secara individu serta memahami kebutuhan pelanggan. Parasuraman et.al, 1985, menjelaskan bahwa emphaty didefiniskan sebagai peduli dan perhatian individu yang disediakan perusahaan terhadap konsumen, termasuk memberikan perhatian kepada konsumen dan pemahaman terhadap karyawan mengenai kebutuhan pelangan serta jam kerja operasional.

\subsection{Kepuasan Nasabah}

Semua pemasar pasti ingin membuat pelanggan merasa puas dengan produk atau jasa yang mereka tawarkan. Kepuasan pelanggan merupakan tingkat perasaan seseorang setelah membandingkan hasil yang dirasakan dengan yang diharapkan (Kotle dan Armstrong, 2010). Menurut Kotler, kepuasan pelanggan akan membentuk perilaku pelanggan untuk : melakukan pembelian ulang, mengatakan hal-hal baik tentang perusahaan kepada orang lain, kurang memperhatikan merek ataupun iklan produk pesaing, membeli produk yang lain dari perusahaan yang sama. Kepuasan merupakan tingkat perasaan seseorang setelah membandingkan kinerja atau hasil yang dirasakan dengan harapannya (Oliver, 1980). Menurut Chen dan Tsai (2007), kepuasan konsumen memiliki dua definisi yaitu : satifaction of chertime transaction and the general or overall satisfaction. Konsumen akan merasa puas apa bila yang diterima pada kenyataannya sesuai bahkan melampaui dari yang diharapkan, ketika hasil yang diharapkan tidak memenuhi harapan mereka, konsumen akan merasa tidak puas. Jadi kepuasan pelanggan dapat digunakan suatu badan usaha untuk menciptakan loyalitas pelanggan. Merupakan hal yang penting untuk mencapai loyalitas pelanggan karena biaya yang diperlukan untuk mendapatkan calon konsumen lebih mahal dibandingkan dengan mempertahankan konsumen lama.

Hanah dan Kar (1991) menyatakan bahwa untuk mencipatakan kepuasan pelanggan, suatu perusahaan harus dapat memenuhi kebutuhan dan keinginan konsumen yang secara umum dibagi menjadi tiga kategori, yaitu : 
a. Faktor yang berhubungan produk

Segala faktor yang berhubungan dengan produk, seperti kualitas produk, harga, bentuk produk atau jasa yang diberikan dan keandalan dari produk atau jasa yang diberikan dan keandalan dari produk atau jasa tersebut dalam menjalankan fungsinya

b. Faktor yang berhubungan dengan pelayanan

Segala faktor yang berhubungan dengan pelayanan yaitu jaminan yang diberikan perusahaan seperti garansi, jaminan harga dan tanggapan perusahaan dalam memecahkan masalah yang dihadapi konsumen atas produk atau jasa tersebut.

c. Faktor yang berhubunagn dengan pembelian

Faktor yang berhubunagn dengan pembelian yang dilakukan konsumen meliputi pengalaman karyawan saat mengkomunikasikan produk atau jasa kepada konsumen dan kemudahan serta kenyamanan yang diberikan oleh perusahaan terhadap produk atau jasa tersebut.

Ada beberapa faktor yang membentuk kepuasan konsumen menurut Zeithaml, Britner dan Gremler (2013) yaitu :

a. Fitur Produk dan Layanan

Konsumen akan melakukan evaluasi terhadap fitur yang terdapat pada suatu produk atau jasa yang di berikan. Jika menurut evaluasi konsumen bahwa produk dan jasa yang diberikan memberikan banyak manfaat sesuai dengan harapannya maka, konsumen akan merasa puas atas produk dan jasa tersebut.

b. Emosi konsumen

Kondisi emosional konsuman saat mengkonsumsi suatu produk atau jasa akan mempengaruhi persepsi konsumen terhadap layanan yang di berikan perusahaan. Jika konsumen tersebut sedang memiliki emosi yang baik seperti sedang gembira, maka konsumen tersebut akan memiliki tingkat toleransi yang tinggi dan lebih mudah di puaskan. Namum sebaliknya jika konsumen sedang memiliki emosi yang buruk seperti sedang marah atau kesal, maka konsumen tersebut akan sangat mudah merasa kecewa atau tidak puas pada pelayanan yang diberikan karena tingkat toleransinya tidak tinggi.

c. Atribusi untuk sukses layanan atau kegagalan

Keberhasilan atau kegagalan dari suatu pelayanan yang diberikan kepada konsumen akan memberikan dampak pada tingkat kepuasan konsumen. Konsumen akan melakukan penilaian dari keberhasilan atau kegagalan pelayanan yang di terimanya.

d. Persepsi ekuitas atau keadilan

Persepsi konsumen mengenai bagaimana mereka di perlakukan, apakah mereka telah di perlakukan sebaik mungkin, atau apakah ada konsumen lain yang mendapat perlakuan lebih baik dari yang di terima oleh dirinya, bagaimana harga yang di tetapkan oleh perusahaan, apakah harga tersebut sebanding dengan manfaat yang di dapat dari produk atau jasa tersebut juga akan mempengaruhi kepuasan konsumen.

e. Konsumen lain, keluarga, anggota dan rekan kerja

Faktor lainnya seperti konsumen lainnya, keluarga, ataupun teman juga akan mempengaruhi kepuasaan dari konsumen tersebut.

3. Hipotesis

Berdasarkan kerangka pemikiran dan model penelitian di atas, maka penulis mengemukakan hipotesis, yaitu :

1. Variabel tangibles, reliability, responsiveness, assurance, emphaty secara bersama-sama berpengaruh signifikan terhadap kepuasan konsumen.

2. Variabel tangibles mempunyai pengaruh dominan terhadap kepuasan konsumen

4. Metode Penelitian

4.1. Identifikasi Variabel Penelitian

Variabel Independen (X) di dalam penelitian ini berjumlah tujuh variabel, yaitu :

$\mathrm{X} 1=\quad$ tangibles

$\mathrm{X} 2=\quad$ reliability 


$$
\begin{array}{ll}
\mathrm{X} 3= & \text { responsiveness } \\
\mathrm{X} 4= & \text { assurance } \\
\mathrm{X} 5= & \text { emphaty }
\end{array}
$$

Sedangkan variabel Dependen (Y) dalam penelitian ini adalah kepuasan konsumen.

4.2. Definisi Operasional

Sesuai dengan identifikasi variabel penelitian, maka setiap variabel tersebut perlu diberi definisi agar tidak terjadi kesalahan dalam penafsirannya, yaitu :

1. Kepuasan konsumen (Y)

Kepuasan konsumen adalah perasaan konsumen setelah membandingkan kinerja atau hasil yang dirasakan dengan harapannya

Indikatornya adalah : kenyamanan, keyakinan, perasaan puas

Dalam penelitian ini, variabel-variabel yang mempengaruhi kepuasan konsumen adalah :

1. Tangibles (X1)

Tangibles adalah bukti nyata dari kepedulian dan perhatian yang diberikan oleh pemilik toko bangunan untuk konsumennya.

Indikatornya adalah : gedung toko, kebersihan, fasilitas toko, kerapihan karyawan

2. Reliability (X2)

Reliability adalah keandalan dalam memberikan pelayanan kepada konsumen

Indikatornya adalah : kecepatan, ketepatan, prosedur

3. Responsiveness (X3)

Responsiveness adalah tanggapan kepada konsumen dilihat dari ketepatan waktu, pelayanan dan pemahaman

Indikatornya adalah : komunikasi, tanggap terhadap keluhan

4. Assurance (X4)

Assurance adalah jaminan pengetahuan, kesopanan karyawan kepada konsumen

Indikator Assurance adalah : keramahan, pengetahuan, jaminan kerahasiaan

5. Emphaty (X5)

Emphaty adalah perhatian dan kepedulian pemilik atau karyawan toko terhadap konsumen,

Indikator emphaty adalah : kesediaan membantu, perhatian individu

Untuk menentukan nilai masing-masing variabel, jawaban diukur dengan scoring berdasarkan skala likert. Nilai skor tertinggi adalah 5 dan terendah adalah 1. Penentuan skor ini berdasarkan pada pendapat Nur Indriantoro dan Bambang Supomo (1999:77) bahwa seorang peneliti dalam menentukan skor ada yang mengemukakan jenjang $3(1,2,3)$, jenjang $5(1,2,3,4,5)$ dan jenjang $7(1,2,3,4,5,6,7)$.

Proses pemberian skor pada variabel-variabel penelitian ini adalah sebagai berikut :

1. Skor 1 adalah kategori sangat tidak sesuai

2. Skor 2 adalah kategori tidak sesuai

3. $\quad$ Skor 3 adalah kategori cukup sesuai

4. $\quad$ Skor 4 adalah kategori sesuai

5. Skor 5 adalah kategori sangat sesuai

Untuk mendapatkan kelas interval dalam pengelompokkan dari skoring 1 sampai dengan 5, dilakukan dengan cara menghitung nilai rata-rata dari masing-masing responden. Interval dihitung dengan rumus :

$$
\frac{\text { Nilai tertinggi }- \text { Nilai terendah }}{\text { Jumlah kelas }}=\frac{5-1}{5}=0,8
$$

\subsection{Waktu dan Lokasi Penelitian}

Penelitian dilakukan di tiga toko bangunan yang berlokasi di Sangatta, yaitu toko bangunan di Sangatta Utara, Sangatta Selatan dan Jalan Bontang. Penelitian dilakukan tahun 2015

4.4. Sumber Data

Jenis data yang digunakan adalah data kualitatif yang diperoleh dari :

1. Data Primer 
Pengumpulan data secara langsung dengan metode kuesioner (daftar pertanyaan) dan interview (wawancara) kepada responden. Data primer tersebut adalah : insentif, kompetensi, motivasi, disiplin kerja, lingkungan kerja, jaminan sosial, gizi dan kesehatan. Kuesioner yang dibuat ada dua jenis, yaitu kuesioner penilaian kinerja yang dibuat untuk level atasan kepada bawahannya (sampai dengan kepala seksi) dan kuesioner untuk seluruh pegawai.

2. Data Sekunder

Pengumpulan data sekunder diperoleh dari Dinas Kesehatan yaitu dengan metode pencarian data melalui buku laporan tahunan dan mengakses data internet.

4.5. Populasi dan Sampel

Menurut Kuncoro (2003:103) dalam bukunya Metode Riset Untuk Bisnis dan Ekonomi : Bagaimana Menulis dan meneliti Penelitian ini mengatakan populasi adalah kelompok elemen yang lengkap yang biasanya berupa orang, objek, transaksi atau kejadian dimana kita tertarik untuk mempelajarinya atau menjadikan objek penelitian. Populasi penelitian ini berjumlah 150 konsumen yang berbelanja di toko bangunan pada tiga lokasi yang dimaksud. Jumlah sampel yang diambil berdasarkan teknik sampel acak.

4.6. Teknik Pengumpulan Data

Di dalam penelitian ini, peneliti menggunakan teknik pengumpulan data sebagai berikut :

1. Kuesioner

Teknik pengumpulan data dengan menggunakan daftar pertanyaan yang dijawab oleh responden

2. Observasi

Pengamatan langsung ke objek yang menjadi pusat penelitian guna mendapatkan dan mengumpulkan data yang diperlukan dalam penelitian dan penulisan penelitian ini.

3. Penelitian dokumen

Penelitian dengan memeriksa catatan-catatan atau file dari bank data karyawan yang ada hubungannya dengan penelitian

4. Wawancara

Melakukan pembicaraan secara langsung kepada para petugas yang ada dilokasi penelitian untuk mendapatkan atau memperoleh petunjuk-petunjuk, keterangan-keterangan yang dapat melengkapi data yang ada.

4.7. Teknik Analisis dan Pengujian Hipotesis

Untuk mengetahui besarnya hubungan antara variabel-variabel bebas $(\mathrm{X})$ terhadap variabel terikat $(\mathrm{Y})$ atau untuk mengetahui sejauh mana variabel-variabel bebas $(\mathrm{X})$ berpengaruh terhadap variabel terikat $(\mathrm{Y})$ dan disamping itu karena menggunakan variabel bebas lebih dari satu, maka model analisis yang digunakan adalah model regresi linier berganda.

$\mathrm{Y}=\mathrm{a}+\mathrm{b} 1 \mathrm{X} 1+\mathrm{b} 2 \mathrm{X} 2+\mathrm{b} 3 \mathrm{X} 3+\mathrm{b} 4 \mathrm{X} 4+\mathrm{b} 5 \mathrm{X} 5+\mathrm{e}$

dimana: $\quad \mathrm{Y}=$ kepuasan konsumen

$\mathrm{X} 1=$ tangibles

$\mathrm{X} 2=$ reliability $\quad \mathrm{a}=$ konstanta

$\mathrm{X} 3=$ responsiveness $\quad \mathrm{b} 1, \mathrm{~b} 2, \mathrm{~b} 3, \mathrm{~b} 4, \mathrm{~b} 5, \mathrm{~b} 6, \mathrm{~b} 7=$ koef. regresi

$\mathrm{X} 4=$ assurance $\quad \mathrm{e}=$ error $/$ kesalahan

1. Teknik Analisis

X5 = emphaty

Teknik analisis yang dilakukan dalam penelitian ini adalah menggunakan analisis kuantitatif. Data dianalisis dengan menggunakan model analisis regresi berganda dengan bantuan program SPSS 14 dengan langkah sebagai berikut :

1) Menentukan koefisien regresi untuk masing-masing variabel bebas multipel korelasi (R) untuk masing-masing variabel bebas $(\mathrm{X})$ terhadap variabel tergantung $(\mathrm{Y})$.

2) Korelasi partial (r) untuk setiap variabel bebas (X)

3) Hasil uji F dan uji t

4) Tingkat probabilitas masing-masing variabel 
Jika R2 hasilnya mendekati 0 (nol), maka pengaruhnya lemah. Secara umum, dapat dikatakan bahwa besarnya suatu koefisien determinasi (R2) berada antara 0 dan 1 atau $0<\mathrm{R} 2<1$. Koefisien determinasi adalah salah satu nilai statistik yang dapat digunakan untuk mengetahui apakah ada hubungan antara dua variabel. Menurut Algifari (2000:45), nilai koefisien determinasi menunjukkan persentase variasi nilai dependen variabel yang dapat dijelaskan oleh persamaan regresi yang dihasilkan. Sedangkan koefisien korelasi (R) merupakan ukuran yang dapat digunakan untuk mengetahui bagaimana keeratan suatu variabel dengan variabel lain.

2. Pengujian Hipotesis

Untuk menguji apakah hipotesis pertama yang diajukan ditolak atau diterima, maka dilakukan melalui uji F sebagai berikut :

1) Pengujian Hipotesis pertama menggunakan uji $\mathrm{F}$ yaitu digunakan untuk mengetahui apakah secara simultan koefisien regresi variabel independen mempunyai pengaruh atau tidak terhadap variabel dependen. Pengujian hipotesis dilakukan dengan tingkat kepercayaan $95 \%(œ=5 \%)$.

Kriteria Hipotesis :

Ho : b1 : b2 : b3 : b4 : b5 =0

Ha : b1 : b2 : b3 : b4 : b5 \# 0

Apabila nilai F Hitung lebih besar dari pada F Tabel, maka hipotesis 0 (Ho) ditolak dan Hipotesis alternatif (Ha) di terima.

2) Pengajuan hipotesis kedua dilakukan dengan Uji t, yaitu untuk menguji pengaruh variabel bebas secara terpisah terhadap variabel tidak bebas.

Kriteria Hipotesis :

Ho : $\mathrm{b} 1=0$

Ha : b1 \# 0

Apabila nilai t Hitung lebih besar dari t Tabel, maka hipotesis 0 (Ho) ditolak dan Hipotesis alternatif (Ha) diterima. Untuk melihat pengaruh dominan yang berasal dari Uji t dengan melihat nilai standar koefisien Beta terbesar.

3) Pengujian Asumsi Klasik

Pengujian terhadap asumsi klasik yaitu pengujian dengan asumsi yang mendasari pelaksanaan regresi linier berganda supaya hasilnya dapat diandalkan, maka perlu diuji multikolinieritas, heteroskedasitas dan autokorelasi.

a). Uji Multikolinieritas

Menurut Ghozali (2005:91), uji multikolinieritas bertujuan untuk mengetahui apakah pada model regresi ditemukan adanya korelasi antar variabel bebas (independen). Model regresi yang baik seharusnya tidak terjadi korelasi diantara variabel independen. Untuk mendeteksi terjadinya multikolinearitas dapat dilihat berdasarkan hasil variance inflation factor (VIF). Nilai cutoff yang umum dipakai untuk menujukkan adanya multikolinearitas adalah nilai-nilai toleransi < 0,10 atau sama dengan nilai VIF > 10.

b). Uji Heteroskedastisitas

Menurut Ghozali(2005:95) uji heteroskedastisitas digunakan menguji dalam model regresi terjadi ketidaksamaan variance dari residual satu pengamatan ke pengamatan lain. Untuk mendeteksi ada atau tidaknya heteroskedstisitas yaitu melihat penyebaran dari varian residualnya.

c). Uji Autokorelasi

Autokorelasi merupakan suatu gejala adanya korelasi diantara semua variabel dari serangkaian observasi yang disusun menurut urutan waktu, juga adanya korelasi antara variabel pengganggu (disturbance error). Untuk mengetahui ada atau tidaknya gejala autokorelasi, digunakan cara melakukan pengujian secara rutin atau seri dalam menghitung residu yang ditaksir dalam analisis regresi. Uji gejala ini sangat diperlukan pada penelitian ekspermen. Sedangkan penelitian ini berupa expost - facto sehinga disini tidak dibuktikan secara terinci. Menurut Imam Ghozali dalam bukunya Aplikasi Analisis Multivariate dengan Program SPSS (2005:96), pendekatan dalam masalah autokorelasi 
dilakukan dengan menggunakan uji Durbin - Watson (DW Test). Menurut Algifari dalam bukunya Statistika Induktif (2000:89), untuk mengadopsi adanya suatu model regresi dilakukan dengan uji DurbinWatson (ujiDw).

\subsection{Hasil Penelitian dan Pembahasan}

Pada bagian ini, penulis menguraikan hasil analisis dari variabel yang dimasukkan ke dalam model penelitian. Pada penelitian ini variabel yang dimasukkan pada model yang diteliti sebagai faktor yang berpengaruh terhadap kepuasan pelanggan (Y) adalah variabel tangibles (X1), reliability (X2), responsiveness (X3), assurance (X4) dan empathy (X5). Hal ini sejalan dengan permasalahan dan tujuan yang telah dikemukakan pada bab 1, maka untuk menjawab permasalahan pertama dapat dilihat dari penjelasan dibawah ini.

Tabel.1

Model Summary ${ }^{\mathrm{b}}$

\begin{tabular}{|c|c|c|c|c|c|}
\hline Model & $\mathrm{R}$ & $\mathrm{R}$ Square & $\begin{array}{c}\text { Adjusted R } \\
\text { Square }\end{array}$ & $\begin{array}{c}\text { Std. Error of the } \\
\text { Estimate }\end{array}$ & Durbin-Watson \\
\hline dimension0 1 &, $860^{\mathrm{a}}$ &, 740 &, 726 &, 25148 & 1,565 \\
\hline
\end{tabular}

a. Predictors: (Constant), X5, X1, X3, X2, X4

b. Dependent Variable: Y

Dari tabel model Summary memperlihatkan bahwa nilai korelasi $\mathrm{R}$ sebesar 0,860 dan koefesien determinasi $\mathrm{R}$ square sebesar 0,740 memberikan gambaran bahwa hubungan antara variabel tangibels (X1), reability (X2), responsiveness (X3), assurance (X4), emphaty (X5) terhadap kepuasan pelanggan tergolong kuat. Pengaruh yang dijelaskan oleh variabel tangibels (X1), reability (X2), responsiveness (X3), assurance (X4), emphaty (X5) secara bersama - sama terhadap kepuasan masyarakat sebesar $74 \%$, sisanya dijelaskan oleh variabel lain yang belum masuk dalam model penelitian. Secara partial hasil analisis regresi memperlihatkan bahwa hubungan antara masing - masing variabel yang diteliti dapat dilihat dari Tabel Coeffisien yang disajikan sebagai berikut:

Tabel. 2

Coefficients $^{\mathrm{a}}$

\begin{tabular}{|c|c|c|c|c|c|c|}
\hline & \multirow{2}{*}{ Model } & \multicolumn{2}{|c|}{ Unstandardized Coefficients } & Standardized & \multirow{2}{*}{$\mathrm{t}$} & \multirow{2}{*}{ Sig. } \\
\hline & & B & Std. Error & Beta & & \\
\hline \multirow[t]{6}{*}{1} & \multirow{2}{*}{$\begin{array}{l}\text { (Constant) } \\
\text { (1) }\end{array}$} & ,541 & , 153 & & 3,531 & ,001 \\
\hline & & ,161 & ,045 & 297 & 3,550 & ,001 \\
\hline & $\mathrm{X} 2$ & ,088 & ,061 &, 133 & 1,429 &, 156 \\
\hline & $\mathrm{X} 3$ &, 168 &, 058 & ,269 & 2,873 &, 005 \\
\hline & $\mathrm{X} 4$ & , 194 & ,071 & ,288 & 2,728 & ,008 \\
\hline & $\mathrm{X} 5$ &, 122 & ,044 & 195 & 2,764 & ,007 \\
\hline
\end{tabular}

a Dependent Variabel Y

Tabel diatas memperlihatkan bahwa besarnya nilai koefisien regresi B masing-masing variabel tangibels (X1) terhadap kepuasan masyarakat sebesar 0,161, reability (X2) terhadap kepuasan masyarakat sebesar 0,088, responsiveness (X3) terhadap kepuasan masyarakat sebesar 0,168, assurance (X4) terhadap kepuasan masyarakat sebesar 0,194, emphaty (X5) terhadap kepuasan pelanggan sebesar 0,122. Nilai koefisien regresi masing - masing tersebut memberikan arti bahwa setiap perubahan atau peningkatan variabel dapat menyebabkan pengaruh yang berdampak positif terhadap kepuasan pelangan. Dampak positif terjadi pada variabel tangibels (X1), reability (X2), responsiveness (X3), assurance (X4), emphaty (X5). Hasil analisis yang sama dapat dilihat dari nilai koefisien standard beta masing - masing variabel 
yang bernilai positif. Dari ke lima variabel tersebut yang menunjukkan nilai koefisien beta terbesar adalah variabel assurance, dengan demikian dapat ditafsirkan bahwa variabel tangibles berpengaruh dominan terhadap kepuasan pelanggan toko bangunan. Berdasarkan nilai koefisien regresi masing masing variabel tersebut, maka hubungan fungsional antara variabel dependen dapat diformulasikan dalam persamaan regresi seperti berikut:

$$
\mathrm{Y}=0,541+0,161(\mathrm{X} 1)+0,088(\mathrm{X} 2)+0,168(\mathrm{X} 3)+0,194(\mathrm{X} 4)+0,122(\mathrm{X} 5)+\mathrm{e}
$$

Persamaan tersebut dapat diperhatikan bahwa setiap perubahan atau peningkatan masing - masing variabel independen $\mathrm{X} 1, \mathrm{X} 2, \mathrm{X} 3, \mathrm{X} 4$, dan $\mathrm{X} 5$ terhadap kepuasan pelanggan berdampak meningkatkan nilai Y. Untuk menghasilkan estimasi yang baik maka dalam model analisis regresi tersebut perlu dilakukan evaluasi asumsi klasik dengan melihat terjadi tidaknya multikolinieritas, heteroskedastisitas dan auotokorelasi. Model regresi yang baik seharusnya tidak terjadi korelalsi diantara variabel independen. Ghozali (2005:91) berpendapat untuk mendeteksi terjadinya multikolinieritas dapat dilihat berdasarkan hasil Variance Inflation Factor (VIF). Nilai Cutof yang umum dipakai untuk menunjukkan adanya multikolinieritas adalah nilai - nilai toleransi 0,10 atau sama dengan nilai VIF 10. Berdasarkan lampiran hasil analisis coefisients dapat disajikan hasil evaluasi multikolinieritas seperti tabel berikut:

Tabel.3

Coefficients $^{\mathrm{a}}$

\begin{tabular}{|c|c|c|c|c|c|c|c|c|}
\hline \multirow{2}{*}{\multicolumn{2}{|c|}{ Model }} & \multicolumn{2}{|c|}{$\begin{array}{l}\text { Unstandardized } \\
\text { Coefficients }\end{array}$} & \multirow{2}{*}{$\begin{array}{c}\text { Standardized } \\
\text { Coefficients } \\
\text { Beta } \\
\end{array}$} & \multirow[t]{2}{*}{$\mathrm{t}$} & \multirow[t]{2}{*}{ Sig. } & \multicolumn{2}{|c|}{ Collinearity Statistics } \\
\hline & & B & Std. Error & & & & Tolerance & VIF \\
\hline 1 & (Constant) & ,541 & , 153 & & 3,531 & ,001 & & \\
\hline & $\mathrm{X} 1$ &, 161 & 045 & ,297 & 3,550 & 001 & 901 & 1,109 \\
\hline & $\mathrm{X} 2$ & ,088 & ,061 &, 133 & 1,429 &, 156 & 321 & 3,111 \\
\hline & $\mathrm{X} 3$ &, 168 & ,058 & ,269 & 2,873 & ,005 & 315 & 3,171 \\
\hline & $\mathrm{X} 4$ & ,194 & ,071 & ,288 & 2,728 & ,008 & ,249 & 4,023 \\
\hline & $\mathrm{X} 5$ & ,122 &, 044 & , 195 & 2,764 &, 007 & ,558 & 1,792 \\
\hline
\end{tabular}

Dependent Variable: Y

Tabel diatas memperlihatkan bahwa nilai VIF masing - masing variabel independen yang dimasukkan ke dalam model menunjukkan nilai 10, sehingga dapat disimpulkan tidak terjadi korelasi diamtara variabel independen. Hasil evaluasi analisis heteroskedasitas dari tabel residual statistik dapat disajikan seperti berikut:

Tabel.4

Residuals Statistics ${ }^{\mathrm{a}}$

\begin{tabular}{|l|c|c|c|c|c|}
\hline & Minimum & Maximum & Mean & Std. Deviation & $\mathrm{N}$ \\
\hline Predicted Value & 2,0068 & 3,7739 & 2,8148 &, 41291 & 100 \\
Residual &,- 67554 &, 50817 &, 00000 &, 24505 & 100 \\
Std. Predicted Value & $-1,957$ & 2,323 &, 000 & 1,000 & 100 \\
Std. Residual & $-2,686$ & 2,021 &, 000 &, 974 & 100 \\
\hline
\end{tabular}

Dependent Variable: Y

Menurut Ghozali (2005:95) uji heteroskedastisitas digunakan untuk menguji dalam model regresi terjadinya ketidaksamaan variance dari residual atau pengamatan lain. Untuk mendeteksiada atau tidaknya heteroskedastisitas yaitu dengan melihat penyebaran dari variabel residualnya. Supranto (2000:71) berpendapat bahwa untuk mendeteksi heteroskedastisitas dapat dilihat dari nilai standard residual statistic rata - rata bernilai nol (0), sehingga error model pada analisis regresi berganda ini layak diasumsikan berasal dari populasi dengan variansi yang homogen, atau tidak mengalami heteroskedastisitas. Dari tabel diatas terlihat nilai rata - rata standard variabel preditor sama dengan 0,000, sehingga dapat dinyatakan bahwa tidak adanya heteroskedastisitas. Evaluasi selanjutnya adalah melakukan pengujian terhadap penyimpangan data dengan pendekatan uji Durbin. Menurut Imam 
Ghozali (2005:95), pendekatan dalam masalah autokorelasi digunakan dengan menggunakan uji DurbinWatson (DW Test). Berdasarkan hasil uji Durbin Watson analisis data dapat disajikan sebagai berikut:

Tabel 5

Model Summaryb

\begin{tabular}{|c|c|c|c|c|c|}
\hline Model & $\mathrm{R}$ & $\mathrm{R}$ Square & Adjusted R Square & $\begin{array}{c}\text { Std. Error of the } \\
\text { Estimate }\end{array}$ & Durbin-Watson \\
\hline dimension &, $860 \mathrm{a}$ &, 740 &, 726 &, 25148 & 1,565 \\
\hline
\end{tabular}

a. Predictors: (Constant), X5, X1, X3, X2, X4

b. Dependent Variable: Y

Tabel diatas memperlihatkan bahwa nilai Durbin Watson yang dihasilkan dari proses data adalah sebesar 1,565. Algifahri berpendapat jika nilai Durbin Waston terletak antara nilai 1,08 - 1,66 tidak terdapat adanya auto korelasi. Berdasarkan ketiga hasil evaluasi tersebut dapat disimpulkan bahwa ke lima variabel yang dimasukkan dalam regresi berganda dapat digunakan untuk mengestimasi kepuasan pelanggan toko bangunan Bahtera Teknik.

\section{Pengujian Hipotesis Penelitian}

Dalam penelitian ini pembuktian hipotesis dilakukan dengan uji $\mathrm{F}$ dan uji t. Pengujian dengan uji $\mathrm{F}$ digunakan untuk menguji hipotesis pertama yang menyatakan bahwa secara bersama - sama variabel tangibels (X1), reability (X2), responsiveness (X3), assurance (X4), dan emphaty (X5) terhadap kepuasan pelanggan. Sedangkan untuk membuktikan hipotesis kedua digunakan pengujian uji $t$ untuk menguji secara parsial variabel independen yang dimasukkan dalam model penelitian. berikut:

Hasil uji $\mathrm{F}$ dari lampiran analisis data dapat dilihat pada tabel ANOVA yang disajikan sebagai

Tabel 6
\begin{tabular}{|l|c|c|c|c|c|}
\hline \multicolumn{1}{|c|}{ ANOVA $^{\mathrm{b}}$} \\
\hline Model & Sum of Squares & $\mathrm{df}$ & Mean Square & $\mathrm{F}$ & Sig. \\
\hline 1 Regression & 16,879 & 5 & 3,376 & 53,379 &, $000^{\mathrm{a}}$ \\
Residual & 5,945 & 94 &, 063 & & \\
Total & 22,823 & 99 & & & \\
\hline
\end{tabular}
a. Predictors: (Constant), X5, X1, X3, X2, X4
b. Dependent Variable: Y

Tabel di atas memperlihatkan bahwa nilai signifikansi atau probabilitasnya yang menunjukkan nilai 0,000 lebih kecil dari alpha 0,05, sehingga hasil pengujian disimpulkan bahwa variabel tangibels (X1), reability (X2), responsiveness (X3), assurance (X4), dan emphaty (X5) berpengaruh signifikan terhadap kepuasan pelanggan toko bangunan. Untuk membuktikan hipotesis kedua dilakukan dengan melihat nilai $\mathrm{t}$ dan signifikansi masing-masing variabel dari lampiran hasil uji t yang secara rinci dapat disajikan seperti berikut:

Tabel 7

Hasil Uji t Variabel Penelitian

\begin{tabular}{|l|c|c|c|c|}
\hline \multicolumn{1}{|c|}{ Model } & $\begin{array}{c}\text { Nilai t } \\
\text { hitung }\end{array}$ & $\begin{array}{c}\text { Nilai t } \\
\text { tabel }\end{array}$ & $\begin{array}{c}\text { Nilai Signifikan } \\
\text { (Probabilitas) }\end{array}$ & Kesimpulan Hipotesis \\
\hline Tangibles & 3,550 & 1,96 & 0,001 & Signifikan \\
Realibility & 1,429 & 1,96 & 0,156 & Tidak signifikan \\
Responsiveness & 2,873 & 1,96 & 0,005 & Signifikan \\
Assurance & 2,728 & 1,96 & 0,008 & Signifikan \\
Empathy & 2,764 & 1,96 & 0,007 & Signifikan \\
\hline
\end{tabular}

a Dependent Variabel Y 
Tabel diatas memperlihatkan bahwa nilai hitung t untuk variabel reability (X2), berpengaruh tidak signifikan terhadap kepuasan pelanggan toko bangunan Bahtera Teknik. Variabel tangibels (X1), responsiveness (X3), assurance (X4), dan emphaty (X5) berpengaruh signifikan. Dari ke empat variabel tersebut nilai signifikan terkecil terletak pada variabel tangibles (X1) yaitu $<0,000$ dari pada 0,05, maka disimpulkan variabel tangibles berpengaruh dominan terhadap kepuasan pelanggan.

\section{Pembahasan}

Berdasarkan hasil analisis regresi berganda dari tabel model Summary memperlihatkan nilai korelasi sebesar 0,860 dan koefisien determinasi 0,740. Nilai tersebut menggambarkan bahwa hubungan variabel tangibels (X1), reability (X2), responsiveness (X3), assurance (X4), dan emphaty (X5) secara bersamasama berpengaruh kuat terhadap kepuasan pelanggan toko bangunan. Demikian juga dilihat dari nilai koefisien determinasinya dapat ditafsirkan bahwa pengaruh yang dijelaskan oleh variabel persepsi tangibels (X1), reability (X2), responsiveness (X3), assurance (X4), dan emphaty (X5) berpengaruh secara bersama-sama terhadap kepuasan masyarakat sebesar $74 \%$, sisanya dijelaskan oleh variabel lain yang belum masuk dalam model penelitian. Artinya variabel yang mempengaruhi kepuasan masyarakat tidak terbatas dari lima variabel yang diteliti tetapi masih ada variabel lainnya yang dapat digunakan untuk mengestimasi kepuasan masyarakat, misalnya disiplin kerja, kompetensi, kepemimpinan. Hasil penelitian ini menjawab permasalahan dan membuktikan hipotesis penelitian pertama sejalan dengan teori yang telah dikemukakan, yaitu teori dari Kotler (2000) menyatakan bahwa kepuasan adalah perasaan senang atau kecewa seseorang yang berasal dari perbandingan kesannya terhadap kinerja atau hasil suatu produk dan harapan-harapannya. Pembahasan secara partial dapat dijelaskan sebagai berikut:

1. Variabel Tangibles (X1) berpengaruh signifikan terhadap kepuasan pelanggan. Keadaan ini menggambarkan bahwa persepsi seseorang terhadap gedung kantor, kebersihan, fasilitas kantor dan kerapian pegawai mampu memberikan kepuasan pelanggan. Menurut Parasuraman (1990) Tangibels, atau bukti fisik yaitu kemampuan suatu perusahaan dalam menunjukkan eksistensinya pada pihak eksternal. Penampilan dan kemampuan sarana dan prasarana fisik perusahaan dan keadaan lingkungan sekitarnya adalah bukti nyata dari pelayanan yang diberikan oleh pemberi jasa. Ini meliputi fasilitas fisik (gedung, gudang dan lainnya), teknologi (peralatan dan perlengkapan yang dipergunakan),serta penampilan pegawainya. Secara singkat dapat diartikan sebagai penampilan fasilitas fisik, peralatan, personil, dan materi komunikasi.

2. Variabel Realibility (X2) berpengaruh tidak signifikan terhadap kepuasan masyarakat. Menurut Fandy Tjiptono (1999) Model Kognitif. Penilaian pelanggan berdasarkan pada perbedaan antara suatu kumpulan dari kombinasi atribut yang dipandang ideal untuk individu dan persepsinya tentang kombinasi dari atribut yang sebenarnya. Dengan kata lain penilaian berdasarkan perbedaan yang ideal dengan yang aktual. Apabila yang ideal sama dengan persepsinya maka pelanggan akan puas, sebaliknya apabila perbedaan antara yang ideal dan yang aktual semakin besar maka konsumen semakin tidak puas.

3. Variabel Responsiveness (X3) berpengaruh signifikan terhadap kepuasan masyarakat. Menurut Wikie (1990) dalam Tjiptono (1999) mendefinisikan kepuasan atau ketidakpuasan pelanggan sebagai suatu tanggapan emosional pada evaluasi terhadap pengalaman pelanggan suatu produk atau jasa. Kepuasan pelanggan merupakan evaluasi purnabeli dimana alternatif yang dipilih sekurang-kurangnya sama atau melampaui harapan pelanggan, sedangkan ketidakpuasan timbul apabila hasil tidak memenuhi harapan (Engel, 1990).

4. Variabel Assurance (X4) berpengaruh signifikan terhadap kepuasan masyarakat. Hal ini sejalan dengan teori Schanaar (1991), pada dasarnya tujuan dari suatu bisnis adalah untuk menciptakan pelanggan yang merasa puas. Terciptanya kepuasan pelanggan dapat memberikan beberapa manfaat antara lain, hubungan yang harmonis antara perusahaan dan konsumennya, memberikan dasar yang baik bagi pembelian ulang dan terciptanya loyalitas pelanggan dan membentuk suatu rekomendasi dari mulut ke mulut (word-of-mouth) yang menguntungkan bagi perusahaan. 
5. Variabel Empathy (X5), berpengaruh signifikan terhadap kepuasan masyarakat. Menurut Day (dalam Tse dan Wilton, 1988 dalam Tjiptono, 1999) menyatakan bahwa kepuasan atau ketidakpuasan pelanggan adalah respon pelanggan terhadap evaluasi ketidaksesuaian yang dirasakan antara harapan sebelumnya. Produk dan jasa yang berkualitas mempunyai peranan penting untuk membentuk kepuasan pelanggan (Kotler dan Armstrong, 1996). Maka semakin berkualitas produk dan layanan yang diberikan, kepuasan yang dirasakan oleh pelanggan semakin tinggi.

\section{DAFTAR PUSTAKA}

Augusty, Ferdinand. 2006. Metodologi Penelitian Manajemen. Edisi 2. Semarang: Badan Penerbit Universitas Diponegoro

Fandy Tjiptono. 1999. Strategi Pemasaran. Yogyakarta: Cetakan ketiga, Andi.

Hasan, M. Iqbal, Pokok-pokok Materi Metodologi Penelitian dan Aplikasinya, Ghalia Indonesia, Bogor, 2002

Imam Ghozali, 2006, Aplikasi Analisis Multivariate dengan Program SPSS. Cetakan keempat. Semarang: Badan Penerbit Universitas Diponegoro

Kotler, Philip, (2000), Manajemen Pemasaran, PT. Prenhallindo, Jakarta

Kotler, P., Armstrong, G., Saunders, J. And Wong, V. (1996), Principles of Marketing, The European Edition, Prentice-Hall, Hemel Hempstead, p. 556

Kotler, Philip dan Gary Amstrong, 1996, Dasar-Dasar Pemasaran, Edisi V, jilid 2,

Kotler, Philip, 2007, Alih Bahasa: Benyamin Molan;Penyunting: Bambang Sarwiji, SE;Manajemen Pemasaran, edisi 12 Jilid 2; PT.INDEKS, Jakarta

Lupiyoadi, Rambat. (2001). Manajemen Pemasaran Jasa. Jakarta: Salemba Empat.

Parasuraman. (2001). The Behaviorial Consequenses of Service Quality, Jurnal of Marketing,Vol 60 .

Parasuraman, Berry and Zeithaml, "Perceived Service Qualtiy as a Customer-Based Performance Measure: An Empirical Examination of Organizational Barriers Using an Extended Service Quality Model," Human Resource Management, Fall 1991, pp. 335-64.

Tjiptono, Fandy dan Chandra Gregorius, 2005, Service, Quality dan Satisfaction, Penerbit : Andi, Yogyakarta

Zeithaml, Parasuraman and Berry, Delivering Quality Service - Balancing Customer Perceptions and Expectations_(New York: The Free Press), 1990.

Zeithaml, V., Parasuraman, A., Berry, L (1990) Delevery Quality Service Balancing Customer Perception and Expectation, USA :Free Pres Collier Macmillan Publisher Intermedia, Jakarta. 